
\title{
$\begin{array}{ll}\text { Research Square } & \begin{array}{l}\text { Preprints are preliminary reports that have not undergone peer review. } \\ \text { They should not be considered conclusive, used to inform clinical practice, } \\ \text { or referenced by the media as validated information. }\end{array}\end{array}$
}

\section{CRISPR-cas system in the acquisition of virulence genes in dental-root canal and hospital-acquired isolates of Enterococcus faecalis}

\section{Pourya Gholizadeh}

Tabriz University of Medical Sciences

Mohammad Aghazadeh

Tabriz University of Medical Sciences

Reza Ghotaslou

Tabriz University of Medical Sciences

Mohammad Ahangarzadeh Rezaee

Tabriz University of Medical Sciences

\section{Tahereh Pirzadeh}

Tabriz University of Medical Sciences

\section{Philippe Lanotte}

Universite de Tours Institut Universitaire de Technologie de Tours

Khudaverdi Ganbarov

Baku State University

Milad Bastami

Tabriz University of Medical Sciences

Mehdi Yousefi

Tabriz University of Medical Sciences

Hossein Samadi Kafil ( $\nabla$ kafilhs@tbzmed.ac.ir)

Tabriz University of Medical Sciences https://orcid.org/0000-0001-6026-8795

\section{Research article}

Keywords: Enterococcus faecalis, CRISPR-cas system, virulence genes, phenotypic characteristics, Hospital-acquired bacteria, Dental-root canal bacteria

Posted Date: October 7th, 2019

DOI: https://doi.org/10.21203/rs.2.13402/v2

License: @ (i) This work is licensed under a Creative Commons Attribution 4.0 International License. Read Full License

Version of Record: A version of this preprint was published at Virulence on January 1st, 2020. See the published version at https://doi.org/10.1080/21505594.2020.1809329. 


\section{Abstract}

Introduction Enterococcus faecalis is one of the important causative agents of nosocomial and life-threatening infections in human. Several studies have demonstrated that the presence of CRISPR- cas is associated with antibiotic susceptibility and lack of virulence traits. In this study, we aimed to assess the phenotypic and genotypic virulence determinants in relation to CRISPR elements from the dental-root canals and hospital-acquired isolates of E. faecalis .Methods and materials Eighty-eight hospital-acquired and 73 dental-root canal isolates of E. faecalis were assessed in this study. Phenotypic screening of the isolates included biofilm formation, and gelatinase and hemolysis activities. Genotypical screening using PCR was further used to evaluate the presence of CRISPR elements and different virulence-associated genes such as efaA , esp , cylA , hyl , gelE , ace, ebpR, and asa1 .Results Biofilm formation, and gelatinase and hemolysis activity were detected in $93.8 \%, 29.2 \%$ and $19.2 \%$ of the isolates, respectively. The most prevalent virulence-associated gene was ace , which was followed by efaA, whereas cylA was the least identified. The presence of CRISPR1- cas, orphan CRISPR2 and CRISPR3- cas was determined in $13 \%, 55.3 \%$ and $17.4 \%$ of the isolates, respectively. CRISPR elements were significantly more prevalent in the dental-root canals isolates. An inverse significant correlation was found between CRISPR- cas loci, esp and gelE, while direct correlations were observed in the case of cylA, hyl , gelE (among CRISPR-loci 1 and 3), asa1, ace , biofilm formation, and hemolysis activity.Conclusion Findings, therefore, indicate that CRISPR-cas might prevent the acquisition of some respective pathogenicity factors in some isolates, though not all; so selective forces could not influence pathogenic traits.

\section{Introduction}

Enterococcus faecalis is a Gram-positive natural inhabitant of the mammalian digestive tract, including those of humans. It is also found in soil, plants and dairy food products [4]. E. faecalis also behaves as an opportunistic pathogen causing life-threatening infections in humans, such as endocarditis, meningitis, septicemia, urinary tract infections and others $[6,7]$. E. faecalis is one of the frequent isolates of the endodontic pathogens ranging in terms of prevalence from $30 \%$ to $90 \%$ of the cases $[8,9]$. The restriction system of $E$. faecalis enables the bacterium to acquire, accumulate and further transfer genetic elements potentially encoding antibiotic resistance genes and virulence factors. These virulence factors include exoenzymes and adhesions. Cytolysin is encoded by $c y l$ operon, which is carried by a plasmid or integrated into the chromosome, with both hemolysin and bacteriocin activity [11, 12]. Gelatinase is encoded by the chromosomal gelE gene, which is a zinc metalloprotease; it can hydrolyze gelatin, fibrinogen, collagen, casein, and insulin [13]. Another secreted factor is hyaluronidase, which is encoded by the hyl gene [12]. E. faecalis endocarditis antigen is encoded by the efaA gene, that affects pathogenicity [15]. Cell wallassociated protein (Esp), encoded by pheromone-responsive plasmids or the chromosomal esp gene, is involved in biofilm formation and immune evasion [15]. Aggregation substance, encoded by the asa 1 gene on the sex pheromone-plasmid pAD1, is a surface-bound glycoprotein which mediates the conjugative transfer of plasmids through the clumping of one $E$. faecalis to another and induces the formation of the cell-cell contact [16]. In addition, ebpR encodes an endocarditis- and biofilm-associated pilus regulator, which activates the ebpABC operon [3]. Another adhesion factor is a collagen binding protein encoded by the ace gene, which mediates binding to collagen type I, collagen type IV, and laminin [17].

Clustered regularly interspaced short palindromic repeats (CRISPRs) loci and CRISPR-associated (Cas) protein-encoding genes are present in approximately $45 \%$ of eubacterial genomes sequenced [18]. The mechanism of the action of CRISPR-cas system is summarized in three stages: adaptation, expression, and interference $[19,20]$. In the adaptation stage, a small segment of the invading mobile element is integrated into the CRISPR loci between palindromic repeats [20]. Spacers and repeats of CRISPR are transcribed and processed into small RNAs, known as crRNAs, which trigger endonucleases encoded by cas genes, to target and cleave the invading mobile elements (DNA or RNA) from which the spacers are derived [20-22]. There are three types of CRISPR loci in E. faecalis genome: CRISPR1-cas, orphan CRISPR2, and CRISPR3-cas [14, 23, 24]. CRISPR1-cas and orphan CRISPR2 were first found in the E. faecalis OG1RF strain: CRISPR1 is located between the OG1RF homologue of EF0672 and EF0673, which has the associated cas genes. CRISPR2 is located between the OG1RF homologue of EF2062 and EF2063, which is an orphan consisting only of spacers and palindromes, without any cas genes [23]. CRISPR3 was found in 2 genomes of the strains Fly1, as a fruit fly E. faecalis, and T11, as a urine E. faecalis isolate. CRISPR3 is located between the homologues of the E. faecalis V583 open reading frames EF1760 and EF1759 [14]. CRISPR1 possesses Nmeni subtype-specific gene csn1 and csn2 [14, 23], while CRISPR3 only possesses csn1, not csn2 [14]. Both CRISPR1 and CRISPR2 contain 7 repeats of a 37bp palindromic sequence with no homology to any sequences of the 29bp spacer [23]. Nevertheless, due to small spacer sequences, it is likely that they are derived from the pheromone-responsive type plasmids, plasmids integrated within the E. faecalis V583 genome, and Enterococcal prophage and phage [14]. Recent studies have demonstrated that the CRISPR/Cas system has applications for genome engineering and exerts a strong selective pressure for the acquisition of virulence factors and antibiotic resistance in pathogenic bacteria [14, 25-27]. Mojica et al., for instance, have suggested that the pathogenicity of bacteria is largely controlled by conjugative plasmids and bacteriophages on an evolutionary time scale. As well, those CRISPR spacers that target these mobile elements might affect bacterial pathogenicity and virulence traits [28]. In the Bourgogne study [29], two strains of $E$. faecalis including one with and one without a type II-A CRISPR/Cas system were used to analyze the virulence of these strains on a mouse urinary tract model. In this study, when the strain with CRISPR was used, the virulence appeared to be lower; however, the strain with CRISPR induced more mortality when equal inocula of both were used [29]. In addition, Histological examinations in this study [29] demonstrated that the strain with CRISPR had an increased potential for biofilm formation; as such, colonizing the organs of mouse by this strain was more efficient than that of strains without the CRISPR system. Louwen et al. [30] also suggested that defense by the CRISPR/Cas system could reduce the potential pathogenicity of bacteria when mobile elements could introduce foreign DNA carrying potential virulence traits such as antibiotic resistance and toxins genes; on the other hand, bacterial pathogenicity may be enhanced by controlling gene expression through the CRISPR-Cas system, such as promoting host colonization. In addition, several studies have demonstrated that there is a positive correlation between the absence of CRISPR/Cas system in the clinical, food and environmental origins of $E$. faecalis and the presence of virulence traits and multidrug-resistance genes [14, 31, 32].

In this study, we aimed to assess the phenotypic and genotypic virulence determinants in relation with CRISPR elements from the dental-root canals and hospital-acquired isolates of E. faecalis.

\section{Methods And Materials}




\section{Bacterial strains}

This study was approved by the Regional Ethics Committee of Tabriz (Tabriz University of Medical Sciences, Tabriz, Iran, No. IR.TBZMED.REC.1397.188). A total of 88 isolates of $E$. faecalis were collected from Emam Reza Teaching and Treatment Hospital and pediatric hospitals of Tabriz, Iran. At the same time, in order to collect 73 dental-root canal isolates of E. faecalis, patients in need of endodontic treatment were referred to the clinic of the Faculty of Dentistry at Tabriz University of Medical Sciences, Tabriz, Iran. Briefly, after stages of access cavity preparation by the dentist, tooth and its surroundings were washed by sterile saline solutions and disinfected with $30 \%$ hydrogen peroxide followed by $2.5 \%$ sodium hypochlorite. Preexisting root canal filling was removed by drill and endodontic K-files without using any chemical solvents. After sampling the single-multi-rooted canal of the tooth, paper points were transferred to a tube containing Enterococcal broth (Becton Dickenson microbiology systems, Cockeysville, MD) and cultured on a bile esculin azide agar (Himedia, India) and incubated at $37^{\circ} \mathrm{C}$ for 24-48h [8]. Suspected colony was identified by the standard procedures of microbiology [33, 34] and genotype detection was performed by $d d I E$ primer $[35,36]$, as shown in table 1 . Both clinical and tooth identified isolates for further studies were stored in a trypticase soy broth containing $10 \%$ glycerol at $-70^{\circ} \mathrm{C}$.

\section{Biofilm formation}

Assessment of biofilm formation was done by quantitative biofilm formation in 96-well flat bottom polystyrene microplates under static conditions for $48 \mathrm{~h}$, as previously described [37, 38]. Briefly, for each isolate, a fresh colony cultured on a Muller-Hinton agar (Merck, Germany) containing $1 \%$ glucose was suspended in sterile saline and adjusted to $0.5 \mathrm{McFarland}$. $20 \mu \mathrm{l}$ of the adjusted isolates was cultured in a $180 \mu \mathrm{l}$ trypticase soy broth containing $1 \%$ glucose. After incubation for $48 \mathrm{~h}$ at $37^{\circ} \mathrm{C}$, each well was washed by the $1 \mathrm{X}$ phosphate buffer saline (PBS; pH 7.4), fixed by methanol, and stained by $200 \mu \mathrm{l} 0.1 \%$ crystal violet for $30 \mathrm{~min}$ at room temperature. The excess crystal violet was discarded and washed by water flow. Biofilm formation was measured by the absorbance of the supernatant after being solubilized in $33 \%$ acetic acid at $570 \mathrm{~nm}$ by using a microtiter plate reader (BioTeck, Winooski, USA). The biofilm formation of each isolate was tested in three independent 96 -well microplates and the average of three optical densities (OD) was used as the final biofilm formation value. The cut-off absorbance for biofilm formation was considered higher than $\mathrm{OD}=0.524$, which was the absorbance of the biofilm produced by $E$. faecalis $\operatorname{ATCC}^{\circledR} 29212^{\mathrm{TM}}$. The mean of the Biofilm formation of each isolate was grouped based on their level of distribution $\left(\mathrm{OD}_{570 \mathrm{~nm}} \mathrm{Values}\right)$ and categorized in quartiles higher than the cut-off absorbance and lower than the highest absorbance. Isolates whose absorbance of $\mathrm{OD}_{570 \mathrm{~nm}}$ fell below 0.524 were classed as non-biofilm formation, while those with $0.525-1.087$ and 1.088-1.650 were grouped as low and moderate biofilm formation, respectively. Isolates with a biofilm formation greater than 1.651 were also considered with high biofilm formation.

\section{Gelatinase production and hemolysis test}

Hemolysis activity was assessed by blood agar plates prepared by a brain-heart infusion agar (BHI, biomerieux, Poland, Ltd) containing $5 \%$ of the group $0 \mathrm{Rh}{ }^{+}$ human blood. Cleared or green zone around the colonies was defined as hemolysis following incubation for $24 \mathrm{~h}$ at $37^{\circ} \mathrm{C}$ [39].

Production of gelatinase was assessed by the degradation of gelatin on the X-ray radiographic film, as described by Pickett et al. [40]. The heavy inoculum of individual isolates was cultured in the tubes containing $3 \mathrm{ml} \mathrm{MHB}$ and a strip of the X-ray radiographic film which had been cut into small strips (approximately 6 by $30 \mathrm{~mm}$ ). The tubes were incubated for $24 \mathrm{~h}$ at $37^{\circ} \mathrm{C}$ and the cleared strip was defined as the production of gelatinase.

\section{Genotype detection of virulence and cas genes}

Total DNA for each isolate was extracted by the tissue buffer boiling method. Briefly, $20 \mu \mathrm{l}$ tissue buffer ( $0.25 \%$ sodium doedecyl sulfate (SDS) and $0.05 \mathrm{M}$ $\mathrm{NaOH}$ ) were mixed with one colony of bacterial isolate and incubated at $95^{\circ} \mathrm{C}$ for $10 \mathrm{~min}$. The suspension was centrifuged at $13000 \mathrm{~g}$ for one minute and $180 \mu$ l DNase free water was added. Genotype analysis for each isolate was accomplished based on the multiplex polymerase chain reaction (PCR) of virulence determinants encoding the cytolysin activator cylA, hyl, esp, gelE, efaA, asa1, ace, ebpR, CRISPR1-cas, CRISPR1-cas csn1, CRISPR2, CRISPR3-cas and CRISPR3-cas csn1. Each of the primer sequences and the amplified size are shown in table 1. $2 \mu$ of total DNA was used for the multiplex PCR in a $25 \mu \mathrm{l}$ reaction mixture. The mix for the detection of esp, cyl, hyl genes contained $12.5 \mu \mathrm{l}$ of the PCR master mix (Yekta Tajhiz Azma, Iran), with $0.5 \mu \mathrm{M}$ of each primer. The mix for ebp, asa 1 and $e f a A$ had the same condition. The mix for the detection of gelE and ace contained $12.5 \mu$ l of the PCR master mix (Yekta Tajhiz Azma, Iran), $1.5 \mathrm{mM}$-additional $\mathrm{MgCl}_{2}$ and $0.5 \mu \mathrm{M}$ of each primer. The mix for CRISPR1-cas csn1, CRISPR3-cas csn1 and CRISPR1-cas, CRISPR3-cas and CRISPR2 contained $12.5 \mu \mathrm{l}$ of the PCR master mix (Yekta Tajhiz Azma, Iran), 1mM additional MgCl2, and $10 \mathrm{mM}$ of each primer. The amplification condition was carried out with the following thermal cycling conditions: initial denaturation at $95^{\circ} \mathrm{C}$ for 10 min, 34 cycles of amplification consisting of $95{ }^{\circ} \mathrm{C}$ for $30 \mathrm{~s}, 30 \mathrm{~s}$ at $58^{\circ} \mathrm{C}$ for esp, cylA, hyl, $58^{\circ} \mathrm{C}$ for efaA, $56^{\circ} \mathrm{C}$ for gel, ace, $52^{\circ} \mathrm{C}$ for ebpR, asa $1,60{ }^{\circ} \mathrm{C}$ for all cas genes, and $72{ }^{\circ} \mathrm{C}$ for $45 \mathrm{~s}$, with $72{ }^{\circ} \mathrm{C}$ for 5 min in the final polymerization. PCR products were analyzed by electrophoresis in a $1 \%$ agarose gel at $100 \mathrm{~V}$ for $1 \mathrm{~h}$ in a $1 \mathrm{X}$ TBE buffer containing the DNA safe stain. PCR products size was correlated with a 100 based-pair DNA ladder (Yekta Tajhiz Azma, Iran) to confirm the conjunction with their expected PCR amplicon size. In addition, the PCR procedure for each isolate was carried out twice in the case of each primer in order to check the consistency and reproducibility.

\section{Statistical analysis}

SPSS software, version 17.0, (Chicago, IL, USA) was used for statistical analysis. T-test and one-tailed Fisher's exact test were performed for data analysis. Significance was set at $\mathrm{P} \leq 0.05$.

\section{Results}

In this study, 88 hospital-acquired and 73 dental-root canal isolates of $E$. faecalis were collected. The specimen sources of hospital-acquired isolates included urinary tract infection (UTI) $(78,88.6 \%)$, wound $(7,7.9 \%)$ and blood $(3,3.4 \%)$. The specimens were obtained from different wards including outpatients (35, 
$39.8 \%)$, intensive $(23,26.1 \%)$, intensive care units (ICU) (12, 13.6\%), infectious ward (13, 14.8\%), emergency ward (3, 3.4\%), ear-nose-throat (ENT) (1, 1.1\%), urology and nephrology (1, 1.1\%). 42 (47.7\%) isolates were from male and 46 (52.3\%) were from female cases. The age range of patients was from 2 months to 86 years, with a mean of 39.04 years. In dental-root canal isolates, $49(67.1 \%)$ of the isolates were obtained from the males and 24 (32.9\%) from the females. The age range of endodontic treatment patients was $12-66$ years, with a mean of 32.41 years. All isolates were investigated for the biofilm formation, in which the minimum, maximum and average of biofilm formation (OD570 nm) were 0.054, 2.325 and 1.611, respectively. Most isolates showed strong biofilm formation $(94,58.4 \%)$, while $10(6.2 \%)$ displayed no biofilm formation. Biofilm formation of hospital-acquired isolates was significantly higher than the dental root canal isolates $(P=0.023)$. Most of the isolates showed no gelatinase activity $(70.8 \%)$, while hospital-acquired isolates significantly displayed the most gelatinase activity $(P=0.001)$. In addition, most isolates showed no hemolysis activity $(80.7 \%)$, and all hemolysis activity was found in hospital-acquired isolates (19.2\%). The most presence of the virulence genes among isolates were ace and $e f a A$ genes ( $88.8 \%$ and $85.1 \%$, respectively), and the lowest one belonged to $c y / A$ and $\operatorname{asa} 1$ (7.5\% and $14.9 \%$, respectively). The presence of gelE (contributing to gelatinase activity) and $c y / A$ (contributing to hemolysis activity) was significantly associated with phenotype gelatinase and hemolysis activity, respectively $(P<0.001, P=0.013)$. In addition, the presence of efaA, $c y / A$, and gelE was significantly more in hospital-acquired isolates, as compared to dental-root canal $(P=0.002, P<0.001, P=0.008$, respectively). By comparing the presence of virulence genes among isolates, it was found that hospital-acquired isolates had higher virulence genes than dental root canal isolates $(P=0.007)$, such that all isolates had at least one virulence gene. The number of virulence genes was 1 to 7 among hospital-acquired isolates and 1 to 6 in the case of dental root canal isolates. Among hospital-acquired isolates, the presence of 5 and 4 virulence genes was the highest (36.4\% and $30.7 \%$, respectively); also, the presence of 4 and 3 virulence genes was the highest among isolates of the dental root canal (39.7\% and $31.5 \%$, respectively). In addition, $e f a A$ and gelE positive isolates had a higher biofilm formation than negative isolates in all isolates $(P<0.05)$. The mean of biofilm formation of the isolates with different virulence genes is presented in figure 1.

The occurrence of CRISPR-cas is shown in table 3. Overall, the presence of CRISPR1-cas loci in dental-root canal isolates (4 of 73) was lower than that of hospital-acquired isolates (17 of 88) $(P=0.008)$, whereas the presence of CRISPR3-cas in dental-root canal isolates (26 of 73$)$ was higher than that of hospital-acquired isolates (2 of 88) $(P<0.001)$; also, orphan CRISPR2 made no difference between hospital-acquired and dental-root canal isolates. None of the isolates had, however, both of CRISPR1-cas and CRISPR3-cas, as well as CRISPR1-cas, orphan CRISPR2, and CRISPR3-cas, at the same time. The isolates were more likely to harbor orphan CRISPR2 than CRISPR1-cas and CRISPR3-cas. In addition, the presence of orphan CRISPR2 was significantly correlated with CRISPR1-cas $(P=0.031)$, whereas it was not significant with CRISPR3-cas. At least one CRISPR-cas locus was found in 106 (65.8\%) of all isolates. The results, therefore, showed the isolates containing high virulence genes tended to have more frequently investigated cas genes. Overall, the absence of CRISPR1-cas in association with one of CRISPR1 or CRISPR3 was significantly correlated with the presence of the esp gene $(P=0.005, P=0.033)$. In addition, the presence of either CRISPR1-cas or orphan CRISPR2 and either CRISPR3-cas or orphan CRISPR2 was significantly correlated with the presence of ace and the absence of gelE, respectively $(P=0.012, P=0.052)$. Other significant correlations were found between the absence of CRISPR1 and the absence of $c y / A$, hyl, gelE, asa $1(P<0.05)$, and between the absence of CRISPR2 and the absence of gelE $(P=0.001)$. In hospital-acquired isolates, a significant correlation was found between the absence of CRISPR loci and the absence of gelE, asa 1, gelatinase and hemolysis activity $(P<0.05)$; in dental-root canal isolates, a significant correlation was found between the absence of CRISPR3-cas and the absence of gelatinase $(P=0.003)$, between the absence of either CRISPR1cas or CRISPR2-cas and the absence of gelE $(P=0.021)$, and between the presence of orphan CRISPR2 and either orphan CRISPR2 or CRISPR3-cas and biofilm production $(P=0.046, P=0.044$, respectively) (see table 4$)$.

\section{Discussion}

In this study, we determined the occurrence of CRISPR loci and the content of virulence factors in E. faecalis strains isolated from different infectious sources as a pathogenic organism and the dental-root canal of patients. We found that the presence of CRISPR1 and CRISPR3 loci was varied among $E$. faecalis strains. The abundance of CRISPR1 among the dental-root canal isolates was significantly lower than that of hospital-acquired ones, whereas the reverse was significantly true for CRISPR3. These results were consistent with those obtained by Burley et al. study [31], who found the presence of CRISPR3-cas was significantly more in endodontic strains, as compared to hospital-acquired strains, and the majority of strains had CRISPR3. While these results were interesting, the reasons were not clear.

The results revealed that the presence of CRISPR loci was not significantly associated with a less number of virulence factors. There are several virulence factors in E. faecalis which play such roles as antiphagocytosis, adherence, biofilm formation, exoenzyme, toxin, and quorum sensing system. Although several studies have reported that there is no clear relation between origin isolation or a single gene and pathogenicity, and perhaps the surface proteins of $E$. faecalis cannot be considered as virulence factors [15, 41, 42], we found a correlation between the absence of CRISPR1-cas and the presence of the esp gene and a correlation between the absence of CRISPR1-cas and the absence of $c y / A$ and asa 1 genes. In addition, there was a correlation between the absence of single or multi-CRIPSR loci and the absence of some virulence factors. The cytolysin operon, cob and esp genes reside in the same pathogenicity island, which are located on either the chromosome or on large pheromone-responsive plasmids such as pAD1 [43,44]. The esp gene encodes a large surface protein with a variable number of highly conserved 82 amino acids repeats, contributing to the promotion of primary attachment, colonization and biofilm formation of $E$. faecalis [44]. Our results, therefore, showed that only the efaA gene was significantly associated with biofilm formation in hospital-acquired strains and esp, $h y l$, ace, asa 1, ebpR and $c y / A$ genes were not associated with biofilm formation. Conflict outcomes have been, however, published regarding the role of the genes of biofilm formation. Duggan et al. , for example, suggested that asa1, cylA, esp and gelE were not associated with biofilm formation in the oral and endodontic isolates of E. faecalis [45], which is compatible with our results. In addition, the results revealed that $13.6 \%$ of hospital-acquired isolates carried the cylA gene, but only $35.2 \%$ of the isolates expressed hemolysin activity (both alpha and beta hemolysis). Several studies such as Sun et al. [46], Sedgley et al. [47] and Lindenstrauß et al. [32] have also determined 38\%,36\% and 33.3\% of the chronic periodontitis, endotitis-associated, and clinical and food isolates of E. faecalis to be capable of producing hemolysis, respectively. These differences may be due to the differences in the types of blood used for the determination of the hemolysis activity; while we used human blood, others have employed horse and sheep blood. In addition, Sun et al. [46] and Sedgley et al. [47] reported the distribution of the cylA gene was detected only in $17 \%$ and $18.18 \%$ of the isolates, respectively; this was compatible with our results. 
These results may be due to such environmental factors as in vitro and in vivo conditions used to test for phenotypic characters, which could strongly influence gene expression [48] and can be the cause of the differences between our results and those obtained by others in the case of hemolysis activity. In addition, hemolysin activity was encoded by cyloperon in $E$. faecalis, where cylA is the only reading frame required for the expression of the component $\mathrm{A}$, a serine protease. As well, there is no association between CRISPR1-cas, biofilm-formation and hemolysis activity. Several studies have reported that CRISPR loci play an inverse role in some virulence factors and acquisition of antibiotic resistance [14, 31, 32], such as Palmer and Gilmore's study [49] and Burley et al.'s study [31], reporting that CRISPR loci were inversely associated with antibiotic resistance and some virulence factors in E. faecalis strains. In addition, similar to our results, Toro et al. [50] and Touchon et al. [51] reported that there was no significant association with CRISPR-cas and acquisition of integrons, plasmids, antibiotic resistance and virulence genes in Escherichia coli. However, an analysis of 370 other Archaeal and Eubacteria genomes showed that there was potential evidence for the propagation of CRISPR-cas genes to occur via horizontal gene transfer [52]. These findings, therefore, suggested that CRISPR loci could potentially inhibit or prevent some or part of the virulence factors and Pathogenicity Island could not serve as the selective forces to influence the pathogenic traits of E. faecalis.

\section{Conclusion}

The findings of this study indicated that CRISPR-cas might prevent the acquisition of some respective pathogenicity factors in some isolates, though not all; significant inverse correlations were found between CRISPR-cas loci, esp and gelE, while direct ones were found in $c y l A$, $h y l$, gelE (between some CRISPR-loci), asa 1, ace, biofilm formation, gelatinase and hemolysis activities. However, CRISPR-cas could prevent the acquisition of antibiotic resistance genes in $E$. faecalis and other bacteria. Further studies can determine the exact role of CRISPR-cas in the pathogenesis of Enterococcal infections.

\section{Declarations}

Compliance with ethical standards

\section{Funding}

This study was supported by Iran National Science Foundation (INSF) with the grant number 97015174 and Faculty of Medicine, Tabriz University of Medical Sciences.

\section{Conflict of interest}

The authors declare that they have no conflict of interest.

\section{Ethical approval}

This study was approved by the Regional Ethics Committee of Tabriz (Tabriz University of Medical Sciences, Tabriz, Iran, No. IR.TBZMED.REC.1397.188).

\section{Informed consent}

For this study, the formal consent was filled by all participants before any procedure according to the ethics committee approved procedure.

\section{Acknowledgment}

We thank Antwerp University, Belgium, for providing us with the reference strains for study.

\section{Conflict of Interest}

None to declare

\section{References}

1. Shankar V, Baghdayan AS, Huycke MM, Lindahl G, Gilmore MS: Infection-derived Enterococcus faecalisstrains are enriched in esp, a gene encoding a novel surface protein. Infect Immun 1999, 67(1):193-200.

2. Vankerckhoven V, Van Autgaerden T, Vael C, Lammens C, Chapelle S, Rossi R, Jabes D, Goossens H: Development of a multiplex PCR for the detection of asa1, gelE, cylA, esp, and hyl genes in enterococci and survey for virulence determinants among European hospital isolates of Enterococcus faecium. $J$ Clin Microbiol 2004, 42(10):4473-4479.

3. Bourgogne A, Singh KV, Fox KA, Pflughoeft KJ, Murray BE, Garsin DA: EbpR is important for biofilm formation by activating expression of the endocarditis and biofilm-associated pilus operon (ebpABC) of Enterococcus faecalis OG1RF. J Bacterio/ 2007, 189(17):6490-6493.

4. Tannock GW, Cook G: Enterococci as members of the intestinal microflora of humans. In: The Enterococci. American Society of Microbiology; 2002: 101132.

5. Lowe A, Lambert P, Smith A: Cloning of an Enterococcus faecalis endocarditis antigen: homology with adhesins from some oral streptococci. Infect Immun 1995, 63(2):703-706.

6. Mohamed JA, Huang W, Nallapareddy SR, Teng F, Murray BE: Influence of origin of isolates, especially endocarditis isolates, and various genes on biofilm formation by Enterococcus faecalis. Infect Immun 2004, 72(6):3658-3663. 
7. Baldassarri L, Creti R, Recchia S, Pataracchia M, Alfarone G, Orefici G, Campoccia D, Montanaro L, Arciola CR: Virulence factors in enterococcal infections of orthopedic devices. The International journal of artificial organs 2006, 29(4):402-406.

8. Gomes BPFA, Pinheiro ET, Sousa ELR, Jacinto RC, Zaia AA, Ferraz CCR, de Souza-Filho FJ: Enterococcus faecalis in dental root canals detected by culture and by polymerase chain reaction analysis. Oral Surgery, Oral Medicine, Oral Pathology, Oral Radiology, and Endodontology 2006, 102(2):247-253.

9. Hidron Al, Edwards JR, Patel J, Horan TC, Sievert DM, Pollock DA, Fridkin SK: NHSN annual update: antimicrobial-resistant pathogens associated with healthcare-associated infections: annual summary of data reported to the National Healthcare Safety Network at the Centers for Disease Control and Prevention, 2006-2007. Infect Control Hosp Epidemiol 2008, 29(11):996-1011.

10. Nallapareddy SR, Murray BE: Ligand-signaled upregulation of Enterococcus faecalis ace transcription, a mechanism for modulating host-E. faecalis interaction. Infect Immun 2006, 74(9):4982-4989.

11. Gilmore MS, Segarra RA, Booth MC, Bogie CP, Hall LR, Clewell DB: Genetic structure of the Enterococcus faecalis plasmid pAD1-encoded cytolytic toxin system and its relationship to lantibiotic determinants. $J$ Bacterio/ 1994, 176(23):7335-7344.

12. Jett BD, Huycke MM, Gilmore MS: Virulence of enterococci. Clin Microbiol Rev 1994, 7(4):462-478.

13. Su Y, Sulavik M, He P, Makinen K, Makinen P-L, Fiedler S, Wirth R, Clewell D: Nucleotide sequence of the gelatinase gene (gelE) from Enterococcus faecalis subsp. liquefaciens. Infect Immun 1991, 59(1):415-420.

14. Palmer KL, Gilmore MS: Multidrug-resistant enterococci lack CRISPR-cas. MBio 2010, 1(4):e00227-00210.

15. Eaton TJ, Gasson MJ: Molecular screening of Enterococcusvirulence determinants and potential for genetic exchange between food and medical isolates. Appl Environ Microbiol 2001, 67(4):1628-1635.

16. Galli D, Lottspeich F, Wirth R: Sequence analysis of Enterococcus faecalis aggregation substance encoded by the sex pheromone plasmid pAD1. Mol Microbiol 1990, 4(6):895-904.

17. Nallapareddy SR, Qin X, Weinstock GM, Höök M, Murray BE: Enterococcus faecalis adhesin, ace, mediates attachment to extracellular matrix proteins collagen type IV and laminin as well as collagen type I. Infect Immun 2000, 68(9):5218-5224.

18. Grissa I, Vergnaud G, Pourcel C: The CRISPRdb database and tools to display CRISPRs and to generate dictionaries of spacers and repeats. $B M C$ Bioinformatics 2007, 8(1):172.

19. Makarova KS, Haft DH, Barrangou R, Brouns SJ, Charpentier E, Horvath P, Moineau S, Mojica FJ, Wolf YI, Yakunin AF: Evolution and classification of the CRISPR-Cas systems. Nature Reviews Microbiology 2011, 9(6):467.

20. Brouns SJ, Jore MM, Lundgren M, Westra ER, Slijkhuis RJ, Snijders AP, Dickman MJ, Makarova KS, Koonin EV, Van Der Oost J: Small CRISPR RNAs guide antiviral defense in prokaryotes. Science 2008, 321(5891):960-964.

21. Barrangou R, Fremaux C, Deveau H, Richards M, Boyaval P, Moineau S, Romero DA, Horvath P: CRISPR provides acquired resistance against viruses in prokaryotes. Science 2007, 315(5819):1709-1712.

22. Makarova KS, Grishin NV, Shabalina SA, Wolf YI, Koonin EV: A putative RNA-interference-based immune system in prokaryotes: computational analysis of the predicted enzymatic machinery, functional analogies with eukaryotic RNAi, and hypothetical mechanisms of action. Biol Direct 2006, 1(1):7.

23. Bourgogne A, Garsin DA, Qin X, Singh KV, Sillanpaa J, Yerrapragada S, Ding Y, Dugan-Rocha S, Buhay C, Shen H: Large scale variation in Enterococcus faecalis illustrated by the genome analysis of strain OG1RF. Genome Bio/ 2008, 9(7):R110.

24. Haft DH, Selengut J, Mongodin EF, Nelson KE: A guild of 45 CRISPR-associated (Cas) protein families and multiple CRISPR/Cas subtypes exist in prokaryotic genomes. PLoS Comput Biol 2005, 1(6):e60.

25. Marraffini LA, Sontheimer EJ: CRISPR interference limits horizontal gene transfer in staphylococci by targeting DNA. Science 2008, 322(5909):1843-1845.

26. Pourcel C, Salvignol G, Vergnaud G: CRISPR elements in Yersinia pestis acquire new repeats by preferential uptake of bacteriophage DNA, and provide additional tools for evolutionary studies. Microbiology 2005, 151(3):653-663.

27. Gholizadeh P, Aghazadeh M, Asgharzadeh M, Kafil HS: Suppressing the CRISPR/Cas adaptive immune system in bacterial infections. Eur J Clin Microbiol Infect Dis 2017, 36(11):2043-2051.

28. Mojica FJM, Díez-Villaseñor Cs, García-Martínez J, Soria E: Intervening Sequences of Regularly Spaced Prokaryotic Repeats Derive from Foreign Genetic Elements. J Mol Evol 2005, 60(2):174-182.

29. Bourgogne A, Garsin DA, Qin X, Singh KV, Sillanpaa J, Yerrapragada S, Ding Y, Dugan-Rocha S, Buhay C, Shen H et al: Large scale variation in Enterococcus faecalis illustrated by the genome analysis of strain OG1RF. Genome Bio/ 2008, 9(7):R110.

30. Louwen R, Staals RHJ, Endtz HP, van Baarlen P, van der Oost J: The Role of CRISPR-Cas Systems in Virulence of Pathogenic Bacteria. Microbiol Mol Biol Rev 2014, 78(1):74-88.

31. Burley KM, Sedgley CM: CRISPR-Cas, a Prokaryotic Adaptive Immune System, in Endodontic, Oral, and Multidrug-resistant Hospital-acquired Enterococcus faecalis. J Endod 2012, 38(11):1511-1515.

32. Lindenstrauß AG, Pavlovic M, Bringmann A, Behr J, Ehrmann MA, Vogel RF: Comparison of genotypic and phenotypic cluster analyses of virulence determinants and possible role of CRISPR elements towards their incidence in Enterococcus faecalis and Enterococcus faecium. Syst Appl Microbiol 2011, 34(8):553-560.

33. Facklam R, Collins M: Identification of Enterococcus species isolated from human infections by a conventional test scheme. J Clin Microbio/ 1989 , 27(4):731-734

34. Kafil HS, Mobarez AM, Moghadam MF, Hashemi ZS, Yousefi M: Gentamicin induces efaA expression and biofilm formation in Enterococcus faecalis. Microb Pathog 2016, 92:30-35. 
35. Kariyama R, Mitsuhata R, Chow JW, Clewell DB, Kumon H: Simple and reliable multiplex PCR assay for surveillance isolates of vancomycin-resistant enterococci. J Clin Microbiol 2000, 38(8):3092-3095.

36. Kafil HS, Mobarez AM, Moghadam MF: Adhesion and virulence factor properties of Enterococci isolated from clinical samples in Iran. Indian Journal of Pathology and Microbiology 2013, 56(3):238.

37. Kafil HS, Mobarez AM: Assessment of biofilm formation by enterococci isolates from urinary tract infections with different virulence profiles. Journal of King Saud University-Science 2015, 27(4):312-317.

38. Aghazadeh M, Zahedi Bialvaei A, Kabiri F, Saliani N, Yousefi M, Eslami H, Samadi Kafil H: Survey of the Antibiofilm and Antimicrobial Effects of Zingiber officinale (in Vitro Study). Jundishapur J Microbio/ 2016, 9(2).

39. Gaspar F, Crespo M, Lopes MS: Proposal for a reliable enterococcal cytolysin production assay avoiding apparent incongruence between phenotype and genotype. J Med Microbio/ 2009, 58(8):1122-1124.

40. Pickett M, Greenwood J, Harvey S: Tests for detecting degradation of gelatin: comparison of five methods. J Clin Microbio/ 1991, 29(10):2322-2325.

41. Hew CM, Korakli M, Vogel RF: Expression of virulence-related genes by Enterococcus faecalis in response to different environments. Syst Appl Microbiol 2007, 30(4):257-267.

42. Martin B, Garriga M, Hugas M, Aymerich T: Genetic diversity and safety aspects of enterococci from slightly fermented sausages. J App/ Microbio/ 2005, 98(5):1177-1190.

43. Shankar N, Coburn P, Pillar C, Haas W, Gilmore M: Enterococcal cytolysin: activities and association with other virulence traits in a pathogenicity island. Int J Med Microbiol 2004, 293(7):609-618.

44. Shankar N, Lockatell CV, Baghdayan AS, Drachenberg C, Gilmore MS, Johnson DE: Role of Enterococcus faecalissurface protein ESP in the pathogenesis of ascending urinary tract infection. Infect Immun 2001, 69(7):4366-4372.

45. Duggan JM, Sedgley CM: Biofilm Formation of Oral and Endodontic Enterococcus faecalis. J Endod 2007, 33(7):815-818.

46. Sun J, Sundsfjord A, Song X: Enterococcus faecalis from patients with chronic periodontitis: virulence and antimicrobial resistance traits and determinants. Eur J Clin Microbiol Infect Dis 2012, 31(3):267-272.

47. Sedgley CM, Molander A, Flannagan SE, Nagel AC, Appelbe OK, Clewell DB, Dahlén G: Virulence, phenotype and genotype characteristics of endodontic Enterococcus spp. Oral Microbiol Immunol 2005, 20(1):10-19.

48. Finlay BB, Falkow S: Common themes in microbial pathogenicity revisited. Microbiol Mol Biol Rev 1997, 61(2):136-169.

49. Palmer KL, Carniol K, Manson JM, Heiman D, Shea T, Young S, Zeng Q, Gevers D, Feldgarden M, Birren B: High-quality draft genome sequences of 28 Enterococcus sp. isolates. J Bacteriol 2010, 192(9):2469-2470.

50. Toro M, Cao G, Ju W, Allard M, Barrangou R, Zhao S, Brown E, Meng J: Association of clustered regularly interspaced short palindromic repeat (CRISPR) elements with specific serotypes and virulence potential of Shiga toxin-producing Escherichia coli. App/ Environ Microbio/ 2014, 80(4):1411-1420.

51. Touchon M, Charpentier S, Pognard D, Picard B, Arlet G, Rocha EP, Denamur E, Branger C: Antibiotic resistance plasmids spread among natural isolates of Escherichia coli in spite of CRISPR elements. Microbiology 2012, 158(12):2997-3004.

52. Godde JS, Bickerton A: The repetitive DNA elements called CRISPRs and their associated genes: evidence of horizontal transfer among prokaryotes. J Mol Evol 2006, 62(6):718-729.

Tables

Table 1: Primers used for the detection of virulence genes and CRISPR-associated genes. 


\begin{tabular}{|c|c|c|c|c|}
\hline Gene & Primer & Sequence (5' to $\left.3^{\prime}\right)$ & PCR product length (bp) & References \\
\hline \multirow[t]{2}{*}{ esp } & espF & GGAACGCCTTGGTATGCTAAC & \multirow{2}{*}{95} & \multirow{2}{*}[1]{} \\
\hline & espR & GCCACTTTATCAGCCTGAACC & & \\
\hline \multirow[t]{2}{*}{ CylA } & cylF & ACTCGGGGATTGATAGGC & \multirow[t]{2}{*}{688} & \multirow[t]{2}{*}{ [2] } \\
\hline & cylR & GCTGCTAAAGCTGCGCTT & & \\
\hline \multirow[t]{2}{*}{ hyl } & hylF & ACAGAAGAGCTGCAGGAAATG & \multirow[t]{2}{*}{276} & \multirow[t]{2}{*}{ [3] } \\
\hline & hylR & GACTGACGTCCAAGTTTCCAA & & \\
\hline \multirow[t]{2}{*}{$e f a A$} & efaF & TGGGACAGACCCTCACGAATA & \multirow[t]{2}{*}{101} & \multirow[t]{2}{*}{ [5] } \\
\hline & efaR & CGCCTGTTTCTAAGTTCAAGCC & & \\
\hline \multirow[t]{2}{*}{ gelE } & gelF & TATGACAATGCTTTTTGGGAT & \multirow[t]{2}{*}{213} & \multirow[t]{2}{*}{ [2] } \\
\hline & gelR & AGATGCACCCGAAATAATATA & & \\
\hline \multirow[t]{2}{*}{ ace } & aceF & GGAGAGTCAAATCAAGTACGTTGGTT & \multirow[t]{2}{*}{101} & \multirow[t]{2}{*}{ [10] } \\
\hline & aceR & TGTTGACCACTTCCTTGTCGAT & & \\
\hline \multirow[t]{2}{*}{ ebpR } & ebpF & AAAAATGATTCGGCTCCAGAA & \multirow[t]{2}{*}{101} & \multirow[t]{2}{*}{ [3] } \\
\hline & ebpR & TGCCAGATTCGCTCTCAAAG & & \\
\hline \multirow[t]{2}{*}{ asa 1} & asaF & GCACGCTATTACGAACTATGA & \multirow[t]{2}{*}{375} & \multirow[t]{2}{*}{ [2] } \\
\hline & asaR & TAAGAAAGAACATCACCACGA & & \\
\hline \multirow[t]{2}{*}{ CRISPR1-cas csn1 } & For & CAGAAGACTATCAGTTGGTG & \multirow[t]{2}{*}{783} & \multirow[t]{2}{*}{ [14] } \\
\hline & Rev & CСTTCTAAATCTTCTTCATAG & & \\
\hline \multirow[t]{2}{*}{ CRISPR1-cas loci } & For & GCGATGTTAGCTGATACAAC & \multirow[t]{2}{*}{315} & \multirow[t]{2}{*}{ [14] } \\
\hline & Rev & CGAATATGCCTGTGGTGAAA & & \\
\hline \multirow[t]{2}{*}{ CRISPR2 loci } & For & CTGGCTCGCTGTTACAGCT & \multirow[t]{2}{*}{ variable } & \multirow[t]{2}{*}{ [14] } \\
\hline & Rev & GCCAATGTTACAATATCAAACA & & \\
\hline CRISPR3-cas csn 1 & For & GCTGAATCTGTGAAGTTACTC & 258 & {$[14]$} \\
\hline & Rev & CTGTTTTGTTCACCGTTGGAT & & \\
\hline CRISPR3-cas loci & For & $\begin{array}{l}\text { GATCACTAGGTTCAGTTATTTC } \\
\end{array}$ & 224 & [14] \\
\hline & Rev & CATCGATTCATTATTCCTCCAA & & \\
\hline
\end{tabular}

Table 2: Genotypic and phenotypic determinants of hospital-acquired and dental-root canal isolates.

\begin{tabular}{|c|c|c|c|c|c|c|c|c|c|c|c|c|c|c|c|c|c|}
\hline & esp & CylA & hyl & $e f a A$ & gelE & ace & $e b p R$ & asa1 & \multicolumn{2}{|c|}{ Gelatinase } & \multicolumn{3}{|c|}{ Hemolysis } & \multicolumn{4}{|c|}{ biofilm formation } \\
\hline Source & $P(n)$ & $P(n)$ & $P(n)$ & $P(n)$ & $P(n)$ & $\mathrm{P}(\mathrm{n})$ & $P(n)$ & $\mathrm{P}(\mathrm{n})$ & $\mathrm{P}$ & $\mathrm{N}$ & $\alpha$ & $\beta$ & $\gamma$ & $\mathrm{N}$ & + & ++ & +++ \\
\hline $\begin{array}{l}\text { Hospital- } \\
\text { acquired (88) }\end{array}$ & $\begin{array}{c}73.9 \% \\
(65) \\
\end{array}$ & $\begin{array}{c}13.6 \% \\
(12) \\
\end{array}$ & $\begin{array}{c}15.9 \% \\
(14) \\
\end{array}$ & $\begin{array}{c}93.2 \% \\
(82)\end{array}$ & $\begin{array}{c}37.5 \% \\
(33) \\
\end{array}$ & $\begin{array}{c}88.6 \% \\
(78)\end{array}$ & $\begin{array}{c}79.5 \% \\
(70)\end{array}$ & $\begin{array}{c}15.9 \% \\
(14)\end{array}$ & $\begin{array}{c}39.8 \% \\
(35) \\
\end{array}$ & $\begin{array}{c}60.2 \% \\
(53)\end{array}$ & $\begin{array}{c}29.5 \% \\
(26)\end{array}$ & $\begin{array}{c}5.7 \% \\
(5) \\
\end{array}$ & $\begin{array}{c}64.8 \% \\
(57) \\
\end{array}$ & $\begin{array}{c}4.5 \% \\
(4) \\
\end{array}$ & $\begin{array}{c}6.8 \% \\
(6) \\
\end{array}$ & $\begin{array}{c}20.5 \% \\
(18) \\
\end{array}$ & $\begin{array}{c}68.2 \% \\
(60)\end{array}$ \\
\hline Dental root (73) & $\begin{array}{c}68.5 \% \\
(55) \\
\end{array}$ & 0 & $\begin{array}{c}24.7 \% \\
(18) \\
\end{array}$ & $\begin{array}{c}75.3 \% \\
(55) \\
\end{array}$ & $\begin{array}{c}19.2 \% \\
(14)\end{array}$ & $\begin{array}{l}89 \% \\
(65) \\
\end{array}$ & $\begin{array}{c}84.9 \% \\
(62)\end{array}$ & $\begin{array}{c}13.7 \% \\
(10)\end{array}$ & $\begin{array}{c}16.4 \% \\
(12) \\
\end{array}$ & $\begin{array}{c}83.6 \% \\
(61)\end{array}$ & 0 & 0 & $\begin{array}{c}100 \% \\
(73)\end{array}$ & $\begin{array}{c}8.2 \% \\
(6) \\
\end{array}$ & $\begin{array}{c}19.2 \% \\
(14)\end{array}$ & $\begin{array}{l}26 \% \\
(19) \\
\end{array}$ & $\begin{array}{c}46.6 \% \\
(34)\end{array}$ \\
\hline$P$-value ${ }^{\S}$ & 0.282 & $<0.001$ & 0.118 & 0.002 & 0.008 & 0.570 & 0.249 & 0.435 & \multicolumn{2}{|c|}{0.001} & \multicolumn{3}{|c|}{$<0.001$} & \multicolumn{4}{|c|}{0.023} \\
\hline Total (161) & $\begin{array}{c}71.4 \% \\
(115)\end{array}$ & $\begin{array}{l}7.5 \% \\
(12)\end{array}$ & $\begin{array}{c}19.9 \% \\
(32)\end{array}$ & $\begin{array}{c}85.1 \% \\
(137)\end{array}$ & $\begin{array}{c}29.2 \% \\
(47)\end{array}$ & $\begin{array}{c}88.8 \% \\
(143)\end{array}$ & $\begin{array}{l}82 \% \\
(132)\end{array}$ & $\begin{array}{c}14.9 \% \\
(24)\end{array}$ & $\begin{array}{c}29.2 \% \\
(47)\end{array}$ & $\begin{array}{c}70.8 \% \\
(114)\end{array}$ & $\begin{array}{c}16.1 \% \\
(26)\end{array}$ & $\begin{array}{c}3.1 \% \\
(5)\end{array}$ & $\begin{array}{c}80.7 \% \\
(130)\end{array}$ & $\begin{array}{c}6.2 \% \\
(10)\end{array}$ & $\begin{array}{c}12.4 \% \\
(20)\end{array}$ & $\begin{array}{l}23 \% \\
(37)\end{array}$ & $\begin{array}{c}58.4 \% \\
(94)\end{array}$ \\
\hline
\end{tabular}

P: positive; N: negative; $\alpha$ : alpha hemolysin; $\beta$ : beta hemolysin; $\gamma$ : none hemolysin; + : low; ++ : moderate; +++ : strong

- $P$-value calculated between hospital-acquired and dental-root canal.

Table 3: The presence of CRISPR-cas type in hospital-acquired and dental root isolates of E. faecalis.

\begin{tabular}{|c|c|c|c|c|c|c|c|c|c|c|}
\hline CRISPR & $\begin{array}{l}\text { CRISPR1- } \\
\text { cas }\end{array}$ & CRISPR2 & $\begin{array}{l}\text { CRISPR3- } \\
\text { cas }\end{array}$ & $\begin{array}{l}\text { CRISPR1-cas or } \\
\text { CRISPR2 }\end{array}$ & $\begin{array}{l}\text { CRISPR1-cas or } \\
\text { CRISPR3-cas }\end{array}$ & $\begin{array}{l}\text { CRISPR2 or } \\
\text { CRISPR3-cas }\end{array}$ & $\begin{array}{l}\text { CRISPR1-cas and } \\
\text { CRISPR2 }\end{array}$ & $\begin{array}{l}\text { CRISPR1-cas and } \\
\text { CRISPR3-cas }\end{array}$ & $\begin{array}{l}\text { CRISPR2 and } \\
\text { CRISPR3-cas }\end{array}$ & $\begin{array}{l}\text { CRISPR1-cas and CRISPR2 and } \\
\text { CRISPR3-cas }\end{array}$ \\
\hline $\begin{array}{l}\text { Hospital-acquired } \\
\text { isolates (88) }\end{array}$ & $\begin{array}{c}19.3 \% \\
(17)\end{array}$ & $\begin{array}{c}53.4 \% \\
(47)\end{array}$ & $2.3 \%(2)$ & $59.1 \%(52)$ & $21.6 \%(19)$ & $54.5 \%(48)$ & $13.6 \%(12)$ & 0 & $1.1 \%(1)$ & 0 \\
\hline $\begin{array}{l}\text { Dental root isolates } \\
\text { (73) }\end{array}$ & $5.5 \%(4)$ & $\begin{array}{c}57.5 \% \\
(42)\end{array}$ & $\begin{array}{c}35.6 \% \\
(26)\end{array}$ & $58.9 \%(43)$ & $42.5 \%(31)$ & $72.6 \%(53)$ & $5.5 \%(4)$ & 0 & $20.5 \%(15)$ & 0 \\
\hline$P$-value ${ }^{\S}$ & 0.008 & 0.358 & $<0.001$ & 0.554 & 0.004 & 0.014 & 0.070 & NS & $<0.001$ & NS \\
\hline Total (161) & $13 \%(21)$ & $\begin{array}{c}55.3 \% \\
(89)\end{array}$ & $\begin{array}{c}17.4 \% \\
(28)\end{array}$ & $59 \%(95)$ & $31.1 \%(50)$ & $62.7 \%(101)$ & $9.9 \%(16)$ & 0 & $9.9 \%(16)$ & 0 \\
\hline
\end{tabular}

NS: not significant

- $P$-value calculated between hospital-acquired and dental-root canal.

Table 4: Association between genotypic and phenotypic characteristics and the occurrence of CRISPR-cas in E. faecalis. 


\begin{tabular}{|c|c|c|c|c|c|c|c|c|c|c|c|c|c|c|c|c|c|c|}
\hline Gene & $\begin{array}{c}\text { CRISPR1- } \\
\text { present }\end{array}$ & $\begin{array}{c}\text { CRISPR1- } \\
\text { absent }\end{array}$ & $\begin{array}{c}\mathrm{p}- \\
\text { value }\end{array}$ & $\begin{array}{l}\text { CRISPR2- } \\
\text { present }\end{array}$ & $\begin{array}{c}\text { CRISPR2- } \\
\text { absent }\end{array}$ & $\begin{array}{c}\mathrm{p}- \\
\text { value }\end{array}$ & $\begin{array}{l}\text { CRISPR3- } \\
\text { present }\end{array}$ & $\begin{array}{l}\text { CRISPR3- } \\
\text { absent }\end{array}$ & $\begin{array}{c}\mathrm{p}- \\
\text { value }\end{array}$ & $\begin{array}{c}\text { CRISPR1 } \\
\text { or } \\
\text { CRISPR2- } \\
\text { present }\end{array}$ & $\begin{array}{l}\text { CRISPR1 } \\
\text { or } \\
\text { CRISPR2- } \\
\text { absent }\end{array}$ & $\begin{array}{c}\mathrm{p}- \\
\text { value }\end{array}$ & $\begin{array}{c}\text { CRISPR1 } \\
\text { or } \\
\text { CRISPR3- } \\
\text { present }\end{array}$ & $\begin{array}{c}\text { CRISPR1 } \\
\text { or } \\
\text { CRISPR3- } \\
\text { absent }\end{array}$ & $\begin{array}{c}\mathrm{p}- \\
\text { value }\end{array}$ & $\begin{array}{c}\text { CRISPR2 } \\
\text { or } \\
\text { CRISPR3- } \\
\text { present }\end{array}$ & $\begin{array}{c}\text { CRISPR2 } \\
\text { or } \\
\text { CRISPR3- } \\
\text { absent }\end{array}$ & $\begin{array}{r}\text { ] } \\
\text { va }\end{array}$ \\
\hline esp-present & 20 & 95 & \multirow[t]{2}{*}{0.005} & 64 & 51 & \multirow[t]{2}{*}{0.509} & 21 & 94 & \multirow[t]{2}{*}{0.417} & 68 & 47 & \multirow[t]{2}{*}{0.549} & 41 & 74 & \multirow[t]{2}{*}{0.033} & 72 & 43 & \multirow[t]{2}{*}{0.} \\
\hline esp-absent & 1 & 45 & & 25 & 21 & & 7 & 39 & & 27 & 19 & & 9 & 37 & & 29 & 17 & \\
\hline CylA-present & 4 & 8 & \multirow[t]{2}{*}{0.053} & 6 & 6 & \multirow[t]{2}{*}{0.464} & 0 & 12 & \multirow[t]{2}{*}{0.092} & 7 & 5 & \multirow[t]{2}{*}{0.594} & 4 & 8 & \multirow[t]{2}{*}{0.544} & 6 & 6 & \multirow[t]{2}{*}{0.} \\
\hline cylA-absent & 17 & 132 & & 83 & 66 & & 28 & 121 & & 88 & 61 & & 46 & 103 & & 95 & 54 & \\
\hline hyl-present & 1 & 31 & \multirow[t]{2}{*}{0.048} & 20 & 12 & \multirow[t]{2}{*}{0.237} & 6 & 26 & \multirow[t]{2}{*}{0.500} & 21 & 11 & \multirow[t]{2}{*}{0.260} & 7 & 25 & \multirow[t]{2}{*}{0.149} & 23 & 9 & \multirow[t]{2}{*}{0.} \\
\hline hyl-absent & 20 & 109 & & 69 & 60 & & 22 & 107 & & 74 & 55 & & 43 & 86 & & 78 & 51 & \\
\hline efaA-present & 20 & 117 & \multirow[t]{2}{*}{0.139} & 75 & 62 & \multirow[t]{2}{*}{0.461} & 22 & 115 & \multirow[t]{2}{*}{0.214} & 81 & 56 & \multirow[t]{2}{*}{0.557} & 43 & 94 & \multirow[t]{2}{*}{0.518} & 86 & 51 & \multirow[t]{2}{*}{0.} \\
\hline efaA-absent & 1 & 23 & & 14 & 10 & & 6 & 18 & & 14 & 10 & & 7 & 17 & & 15 & 9 & \\
\hline gelE-present & 7 & 40 & \multirow[t]{2}{*}{0.415} & 35 & 12 & \multirow[t]{2}{*}{0.001} & 5 & 42 & \multirow[t]{2}{*}{0.108} & 36 & 11 & \multirow[t]{2}{*}{0.003} & 12 & 35 & 0.217 & 36 & 11 & 0. \\
\hline gelE-absent & 14 & 100 & & 54 & 60 & & 23 & 91 & & 59 & 55 & & 38 & 76 & & 65 & 49 & \\
\hline ace-present & 20 & 123 & 0.282 & 84 & 59 & 0.012 & 26 & 117 & 0.358 & 89 & 54 & 0.019 & 46 & 97 & 0.285 & 94 & 49 & 0 . \\
\hline ace-absent & 1 & 17 & & 5 & 13 & & 2 & 16 & & 6 & 12 & & 4 & 14 & & 7 & 11 & \\
\hline ebpR-absent & 3 & 26 & & 14 & 15 & & 4 & 25 & & 15 & 14 & & 8 & 21 & & 16 & 13 & \\
\hline $\begin{array}{l}\text { asa1- } \\
\text { present }\end{array}$ & 6 & 18 & 0.067 & 15 & 9 & 0.293 & 3 & 21 & 0.363 & 17 & 7 & 0.146 & 9 & 15 & 0.303 & 16 & 8 & 0. \\
\hline asa1-absent & 15 & 122 & & 74 & 63 & & 25 & 112 & & 78 & 59 & & 41 & 96 & & 85 & 52 & \\
\hline $\begin{array}{l}\text { Biofilm- } \\
\text { positive }\end{array}$ & 19 & 132 & 0.384 & 86 & 65 & 0.092 & 27 & 124 & 0.453 & 91 & 60 & 0.176 & 46 & 105 & 0.377 & 97 & 54 & 0. \\
\hline $\begin{array}{l}\text { Biofilm- } \\
\text { negative }\end{array}$ & 2 & 8 & & 3 & 7 & & 1 & 9 & & 4 & 6 & & 4 & 6 & & 4 & 6 & \\
\hline $\begin{array}{l}\text { Gelatinase- } \\
\text { positive }\end{array}$ & 4 & 43 & 0.203 & 29 & 18 & 0.190 & 10 & 37 & 0.268 & 30 & 17 & 0.268 & 14 & 33 & 0.490 & 32 & 15 & 0. \\
\hline $\begin{array}{l}\text { Gelatinase- } \\
\text { negative }\end{array}$ & 17 & 97 & & 60 & 54 & & 18 & 96 & & 65 & 49 & & 36 & 78 & & 69 & 45 & \\
\hline $\begin{array}{l}\text { Hemolysis- } \\
\text { positive }\end{array}$ & 4 & 27 & 0.623 & 19 & 12 & 0.293 & 0 & 31 & 0.001 & 19 & 12 & 0.469 & 4 & 27 & 0.010 & 19 & 12 & 0. \\
\hline $\begin{array}{l}\text { Hemolysis- } \\
\text { negative }\end{array}$ & 17 & 113 & & 70 & 60 & & 28 & 102 & & 76 & 54 & & 46 & 84 & & 82 & 48 & \\
\hline
\end{tabular}

\section{Figures}

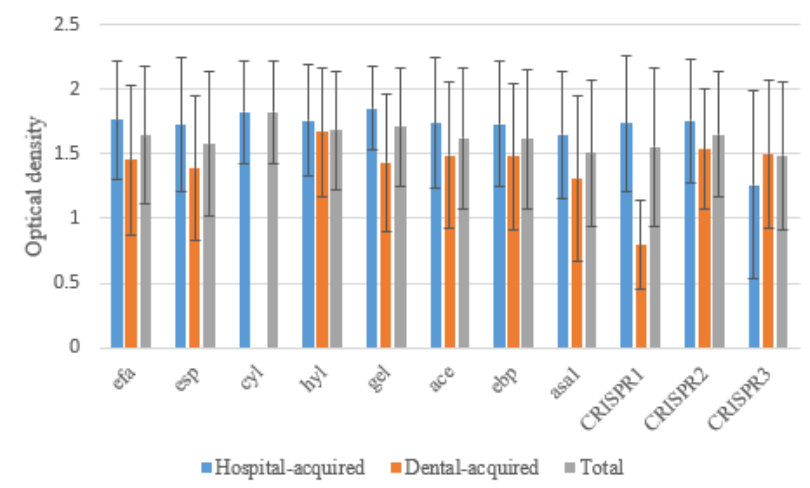

Figure 1

Biofilm formation absorbance by E. faecalis isolates according to the presence of virulence factors and CRISPR loci. (Error bars illustrate the standard deviation of the absorbance mean) 